\title{
HAK ATAS RUANG HIDUP SUKU ORANG RIMBA (ONTOLOGI, EPISTEMOLOGI, AKSIOLOGI HUKUM ADAT) ${ }^{1}$
}

\author{
Muhamad Erwin \\ Fakultas Hukum Universitas Sriwijaya \\ Jalan Srijaya Negara, Kampus Bukit Besar, Palembang \\ Email: erwin_muhamad@ymail.com
}

\begin{abstract}
Indigenous law institution of Orang Rimba tribes is related by the cosmos of Bukit Duabelas forest. This article explores how the construction of ontology, epistemology, axiology of Indigenous law Orang Rimba tribes in related with the rights of their living space. This research is an empirical legal study. Based on the research that is ontology, epistemology and axiology, legal substance tribal indigenous Orang Rimba located on their own, which occurred on their life situation when dealing with natural conditions Bukit Duabelas. That understanding is because they feel conscious of their interaction with Bukit Duabelas as their living space through the principle of humane, holistic, responsibility and contextualization, where the values are independent from each other.
\end{abstract}

Keywords: Ontology; Epistemology; Axiology; Indigenous Law; Rights of Living Space

\begin{abstract}
Abstrak
Kelembagaan hukum adat suku Orang Rimba begitu bertalian dengan keberadaan kosmos hutan Bukit Duabelas. Tulisan ini menelusuri tentang bagaimana konstruksi berpikir ontologi, epistemologi dan aksiologi hukum adat suku Orang Rimba hubungannya dengan hak atas ruang hidupnya di Bukit Duabelas. Penelitian ini merupakan penelitian empiris dengan pendekatan historis-filosofis. Berdasarkan hasil penelitian bahwa secara ontologi, epistemologi dan aksiologi, substansi hukum adat suku Orang Rimba terletak pada adat mereka sendiri, yang terjadi dari situasi kehidupan mereka ketika berhadapan dengan kondisi alam Bukit Duabelas. Pemahaman tersebut terjadi karena mereka merasa sadar atas interaksinya dengan hutan Bukit Duabelas sebagai ruang hidupnya melalui prinsip humanis, holistik, tanggung jawab dan kontekstualisasi, dimana nilainilai tersebut memiliki keterkaitan satu sama lain.
\end{abstract}

Kata Kunci: Ontologi; Epistemologi; Aksiologi; Hukum Adat; Hak atas Ruang Hidup.

\section{A. Pendahuluan}

1. Latar Belakang Permasalahan

Hidup adalah pilihan, maka pada hakikatnya tidak diperkenankan adanya pihak mana pun untuk mengatur dan menciderai hak hidup orang lain yang fitrahnya adalah sebuah hak asasi. ${ }^{2}$ Hukum adat adalah suatu hukum yang hidup, karena ia menjelmakan perasaan hukum yang nyata dari rakyat. Sesuai dengan fitrahnya sendiri, hukum adat terus-menerus dalam keadaan tumbuh dan berkembang seperti hidup itu sendiri. Jauh sebelum negara Republik Indonesia berdiri, suku Orang
Rimba telah hidup di Bukit Duabelas sebagai persekutuan masyarakat hukum adat.

Setelah bangsa Indonesia berdiri, pada salah satu bagian kontrak sosialnya, yakni alinea keempat pembukaan UUD 1945, disebutkan bahwa salah satu tujuan dari dibentuknya negara Indonesia adalah untuk “.....melindungi segenap bangsa Indonesia dan seluruh tumpah darah Indonesia...". Dalam keperluan untuk melindungi segenap bangsa Indonesia tersebut hanyalah dapat didekati dengan pemahaman yang mendalam terhadap kemajemukan budaya hukum yang

1. Artikel hasil Penelitian Mandiri penulis dari bulan Agustus 2015 s.d. Juni 2016.

2. International Covenant on Economic, Social and Cultural Rights, article 2 and 6.

3. Sri Sudaryatmi, "Peranan Hukum Adat dalam Pembangunan Hukum Nasional di Era Globalisasi", Jurnal MasalahMasalah Hukum, Vol. 41, No. 4, Oktober 2012, hlm. 575. 
ada di Indonesia, termasuk dari keberadaan berbagai suku minoritas pribumi, yang dikenal sebagai suku asli (indigenous tribes), orang asli (indigeneous people), seperti suku Orang Rimba di Bukit Duabelas. Sebutan atas "Orang Rimba" sendiri, pada dasarnya merupakan interpretasi dari jati diri hidup mereka yang memandang hukum adat dan hutan Bukit Duabelas sebagai kunci utama hidup mereka sejak nenek moyangnya sebagaimana seloka adatnya adat lamo pesako usang yang berarti hukum adat lama tidak akan berubah, begitu pun dalam kearifan menjaga Bukit Duabelas sebagai ruang hidupnya.

Saat ini, kearifan hubungan antara hukum adat dan Bukit Duabelas sebagai ruang hidup suku Orang Rimba tersebut tengah terganggu oleh dialog kepentingan di antara positivisme hukum dan globalisasi. Konteks pengelolaan kehutanan dan sumber daya alam, maka pemerintah cenderung memberlakukan peraturan perundangundangan sebagai satu-satunya wujud hukum negara yang mengatur pengelolaan ruang hidup. Oleh karenanya, pengaturan yang bertalian dengan hukum adat seringkali diabaikan dalam proses pembentukan peraturan perundang-undangan. Secara substansi, jika dalam undang-undang diatur mengenai hak-hak masyarakat adat atas pengelolaan ruang hidup dan sumber daya alam selalu disertai kalimat "sepanjang tidak bertentangan dengan kepentingan nasional" atau "sepanjang masih ada dan diakui dan seterusnya". Dengan cara inilah pemerintah menjalankan politik hukum dengan pengabaian kemajemukan hukum yang secara nyata hidup dan berlaku di masyarakat adat. Begitu pun dalam tataran substansi politik hukum negara yang selalu hendak mengeluarkan suku Orang Rimba dari hutan Bukit Duabelas melalui program Pemukiman Kembali Masyarakat Terasing (PKMT), dikarenakan kawasan Bukit Duabelas adalah berstatus sebagai taman nasional.

Pada tataran implementasi, pemerintah juga seringkali tidak hadir pada saat kearifan budaya masyarakat suku Orang Rimba dalam pengelolaan dan pemanfaatan hutan Bukit Duabelas melalui hukum adatnya mendapatkan gangguan yang datang dari masyarakat desa yang tinggal di sekitar hutan, golongan masyarakat transmigran atau kelompok investor yang menanamkan modal besar pada sumber daya hutan ulayat suku Orang Rimba di sekitar Bukit Duabelas. Perlakuan semacam ini jelas telah mengabaikan hak atas ruang hidup suku Orang Rimba beserta kearifan hukum adatnya.

Berhadapan dengan kompleksitas permasalahan yang menerpa kearifan budaya hukum suku Orang Rimba tersebut, maka menjadi penting nilainya untuk menelusuri tentang bagaimana konstruksi berpikir atas landasan ontologi, epistemologi, dan aksiologi hukum adat suku Orang Rimba dalam hubungannya dengan hak atas ruang hidup suku Orang Rimba di Taman Nasional Bukit Duabelas tersebut?

\section{Metode Penelitian}

Penelitian ini merupakan penelitian yang berkenaan dengan filsafat hukum. Dipandang sedemikian, karena pada penelitian ini dikaji tentang bagaimana tataran nilai ideal yang terkandung pada konstruksi berpikir ontologis, epistemologis, aksiologis hukum adat suku Orang Rimba terhadap hak atas ruang hidupnya di Bukit Duabelas yang merupakan kajian filsafat hukum. Penelitian ini dilakukan dengan pendekatan historis-filosofis dan dengan kajian empiris secara analitis. Pengumpulan data pada penelitian ini dilakukan dengan metode pengamatan terlibat (participant observation) dan dengan wawancara mendalam (in-depth interview). Penelitian ini dilakukan pada kelompok-kelompok suku Orang Rimba yang ruang hidupnya berada di dalam kawasan suaka alam dan pelestarian alam Taman Nasional Bukit Duabelas yang terletak di Kabupaten Sarolangun, Kabupaten Tebo, dan Kabupaten Batang Hari Provinsi Jambi.

\section{Kerangka Teori}

Keberadaan suku Orang Rimba di Bukit Duabelas dengan keberlakuan hukum adatnya senantiasa berkelindan sebagaimana 
pemikiran $\mathrm{Cicero},{ }^{4}$ dalam adagiumnya bahwa "ubi societas ibi ius" (di mana ada masyarakat, di situ ada hukum). Kemudian pada perkembangan hukum tersebut, menurut Eugen Erlich ${ }^{5}$ begitu bertalian erat dengan nilai-nilai yang dianuti masyarakat sehingga membuat hukum tersebut dapat menjadi hukum yang hidup (leben des recht). Begitu pun dengan bangunan hubungan di antara suku Orang Rimba di Bukit Duabelas dengan hukum adatnya, di mana hukum adat suku Orang Rimba memiliki daya kerja yang konstruktif untuk membangun hak atas ruang hidup dan menyatu dengan kehidupan masyarakat suku Orang Rimba di Bukit Duabelas itu sendiri.

Sebagaimana cara berpikir filsafat hukum adat, hukum adat suku Orang Rimba juga lahir dari nilai-nilai yang dipetik dari nature dan culture, lalu diturunkan ke dalam bentuk ukuran-ukuran etis yang selanjutnya diterangkan dalam kaidah-kaidah yang menjadi dasar untuk tingkah laku yang nyata. Hukum adat suku Orang Rimba di Bukit Duabelas juga memiliki corak atau karakteristik sebagaimana hukum adat pada umumnya yakni: tradisional; magis religius; komunal; konkrit dan visual (jelas, nyata, berwujud); sederhana; tidak tertulis dan tidak dikodifikasi; mengutamakan musyawarah dan mufakat.

Berdasarkan karakteristik berpikir hukum adat yang sedemikian, terdapat tiga ikatan sebagai asas dalam hukum adat yang penulis petik dari natuur dan cultuur sebagai sumber nilai, lalu diturunkan kepada cara berpikir hukum adat yang magis religius, komunal, konkrit, dan kontan. Keseluruhan cara berpikir tersebut semata-mata bertujuan untuk mengembalikan keseimbangan magis religius yang terganggu, sehingga terdapat hubungan yang harmonis. Berdasarkan ketergantungan dari paradigma tersebut, kemudian keseimbangan tersebut diterjemahkan melalui asas: ${ }^{6}$ rukun, patut, dan laras.

Mengalirnya pemikiran ubi societas ibi ius, living law, dan cara berpikir hukum adat sedemikian, maka merupakan suatu kewajaran, jika Satjipto Rahardjo dalam pemikiran hukum progresif ${ }^{7}$ percaya bahwa kekuatan hukum terletak pada masyarakat, karena masyarakat memiliki kekuatan otonom untuk melindungi dan menata dirinya sendiri.

\section{B. Hasil dan Pembahasan}

1. Konstruksi Ontologi Hukum Adat terhadap Hak atas Ruang Hidup Suku Orang Rimba di Taman Nasional Bukit Duabelas

Ontologi merupakan pertanyaan mengenai bagaimanakah bentuk dan sifat dari realitas, berikut apa yang dapat diketahui dari hal tersebut. ${ }^{8}$ Substansi hukum adat suku Orang Rimba secara ontologis terletak pada "adat" mereka sendiri. Adat suku Orang Rimba terjadi dari situasi kehidupan suku Orang Rimba ketika berhadapan dengan kondisi alam Bukit Duabelas, sehingga adat dalam ontologi hukum adat suku Orang Rimba diartikan bahwa Orang Rimba dan alam Bukit Duabelas merupakan peng 'ada' (ontos) bagi adat Orang Rimba sendiri. Hal ini menunjukan bahwa tidak ada adat Orang Rimba tanpa suku Orang Rimba dan alam Bukit Duabelas.

Berdasarkan ajaran turun temurun suku Orang Rimba (tradisional), bentuk-bentuk hukum adat mereka diklasifikasikan atas: hukum lamo; hukum besamo; ${ }^{9}$ hukum pertamo; dan hukum serenggamo. Hukum lamo merupakan hukum yang dapat dipakai selama-lamanya dan tidak dapat berubah (tetap), contohnya dalam penentuan syarat untuk dapat menikah. Sementara, hukum besamo, diterjemahkan sebagai hukum yang

4. Muhamad Erwin, 2016, Filsafat Hukum: Refleksi Kritis Terhadap Hukum dan Hukum Indonesia (Dalam Dimensi Ide dan Aplikasi), Jakarta, PT RajaGrafindo Persada, hlm. 309.

5. Soetandyo Wignjosoebroto, 2007, Hukum Dalam Masyarakat (Perkembangan dan Masalah), Sebuah Pengantar Ke

6. Araca: Shidarta, (Posisi Pemikiran Teori Hukum Adat Mohammad Koesnoe Dalam Konfigurasi Aliran Pemikiran Hukum) dalam Agni Udayati dkk., 2013, Mohammad Koesnoe Dalam Pengembaraan Gagasan Hukum Indonesia, Jakarta, Epistema Institute dan HÜMA, hlm. 40.

7. Satjipto Rahardjo, 2009, Hukum Progresif: Sebuah Sintesa Hukum Indonesia, Yogyakarta, Genta Publishing, hlm. 56.

8. Aditya Yuli Sulistyawan, "Mempersoalkan Objektivitas Hukum: Suatu Perbincangan Filsafat Hukum", Jurnal Masalah-Masalah Hukum, Vol. 41, No. 4, Oktober 2012, hlm. 511.

9. Hasil wawancara dengan Nggrip, Tumenggung wilayah Kedundung Muda (Bukit Duabelas), Jum'at, 5 Februari 2016. 
muncul sebagai akibat belum pernah terdapat putusan hukum adat pada perkara yang unik dan tertentu sehingga dalam pemutusannya dilakukan secara bersama-sama dalam bentuk mufakat oleh seluruh anggota masyarakat suku Orang Rimba di TNBD. Kemudian untuk keberadaan dari hukum pertamo adalah bahwa hukum sebagai kebijaksanaan, sebagai contoh apabila suatu perkara dalam permasalahannya tidak begitu merugikan, maka tidak perlu untuk dihukum. Selanjutnya terhadap keberadaan dari hukum serenggamo adalah dipandang masyarakat suku Orang Rimba sebagai senjata pamungkas, di mana apabila telah diperingatkan masih juga diperbuat, maka hukum akan diterapkan. ${ }^{10}$

Dari bentuk-bentuk hukum adat suku Orang Rimba sedemikian, maka dapat dipahami bahwa berdasarkan sifatnya, hukum adat suku Orang Rimba tersebut memiliki dua sisi kekhasan yang identik dengan tesisnya Snouck Hurgronje, bahwa pada satu sisi, adat adalah keseluruhan hukum dan kebiasaan yang amat tua, yang diadakan oleh nenek moyang, untuk membedakannya dengan segala sesuatu yang berasal dari generasi, yang justru lebih peka terhadap perubahan. Pada sisi lain, istilah adat ini bukan merupakan hasil konstruksi nenek moyang, tetapi sesuatu yang notabene merupakan hasil kesepakatan atau mufakat masyarakat. ${ }^{11} \mathrm{Hal}$ ini tidak terlepas dari hakikat hukum adat itu sendiri sebagai gejala sosial dalam hidup bersama manusia. ${ }^{12}$ Fungsi hukum adat dalam hidup bersama tersebut, menurut Moh. Koesnoe adalah sebagai dasar kehidupan, yang lazim disebut langgam adat, di mana adat dipandang sebagai pemberi arah bagi dasar kehidupan. ${ }^{13}$ Pada titik ini, yang menjadi sifat tertentu dari adat adalah adanya kepercayaan bahwa individu mengabdi pada masyarakat sebagai suatu organisme.

Pada sisi lain, hukum adat sebagai bagian dari gejala sosial selalu tumbuh dan berkembang mengikuti perkembangan masyarakat/zaman. Namun walaupun begitu, hukum adat tetaplah hukum adat, ia tidak kehilangan eksistensinya sekalipun terjadi perubahan bentuk. Menurut Dominikus Rato, secara substansi hukum adat hanyalah mengalami perubahan bentuk luarnya saja (external form) atau formatnya saja, sedangkan substansi isinya (internal substance) tidak mengalami perubahan, sebab hukum adat berisi tentang normanorma yang lahir dari pengalaman dari generasi ke generasi dengan perubahanperubahan yang disesuaikan dengan kebutuhan-kebutuhan nyata anggota masyarakat hukum adat itu selama mereka berinteraksi. $^{14}$

Pemikiran Dominikus Rato tersebut senada dengan realitasnya dalam cara pandang suku Orang Rimba di Taman Nasional Bukit Duabelas dalam memandang hukum yang hendak diberlakukan. Menurut seloka adat suku Orang Rimba, "“'Semenjak gagak itam bekuntul putih, nang undut besundut, uhat beruhat, adat dipegang, pesako dipakai, tiado boleh ditinggolko" (adat yang ditinggalkan nenek moyang itulah yang hendaknya terus dipegang) ${ }^{15}$ Dengan demikian, dapat disimpulkan bahwa hukum adat suku Orang Rimba di Taman Nasional Bukit Duabelas sifatnya "tradisional". Selain itu secara aksidensi, hukum adat suku Orang Rimba begitu didasari oleh kepercayaan yang sifatnya magis religius. Apabila hukum adat yang disampaikan kepada mereka tidak diikuti, maka mereka akan terkena kutukan.

Jika dihubungkan dengan keberadaan hutan Bukit Duabelas sebagai ruang hidup suku Orang Rimba, maka secara substansi hukum adat suku Orang Rimba dipandang bahwa alam hutan Bukit Duabelas adalah pusaka (pesako). Pemahaman ini dapat dibuktikan dengan keteguhan Orang Rimba memandang seloka adatnya yang berbunyi:

Ado rimbo, ado bungo; Ado bungo, ado dewo; Hopi ado rimbo, hopi ado bungo; Hopi ado bungo, hopi ado dewo. Maknanya: Di mana terdapat hutan, disitu terdapat bunga; Di mana terdapat bunga, disitu terdapat dewa; Jika hutan tidak ada lagi, maka tidak terdapat lagi

10. Diolah dari hasil wawancara dengan Meratay, Depati wilayah Kedundung Muda (Bukit Duabelas), Kamis, 26 Mei 2016.

11. Otje Salman Soemadiningrat, 2011, Rekonseptualisasi Hukum Adat Kontemporer, Bandung, PT Alumni, hlm. 108.

12. M. Agus Santoso, 2012, Hukum, Moral, \& Keadilan: Sebuah Kajian Filsafat, Jakarta, Kencana Prenada Media Group, hlm. 129

13. Shidarta, Op.cit., hlm. 28

14. Dominikus Rato, 2015, Hukum Adat Kontemporer, Surabava, LaksBang Justitia, hlm. 25.

15. Hasil wawancara dengan Besemen, Mangku adat wilayah Kedundung Muda (Bukit Duabelas), Senin, 23 Mei 2016. 
bunga; Jika bunga tidak ada lagi, maka tidak ada lagi dewa yang dapat memberikan keberuntungan. ${ }^{16}$

Begitu pun dengan seloka adatnya yang menyebutkan:

Rimbo Bukit Duobelay sebagai pesako, sebagai rimbo dewo, untuk umo, untuk belindung supayo ngon hujan lebat, hopi terlalu teraso, ngon hutan rimbo tejago, angin dak terlalu kencang, rimbo untuk pasohon (makam). (Hutan Bukit Duabelas sebagai pusaka adalah sebagai tempatnya dewa, tempat hidup mereka, tempat berlindung agar supaya jika terjadi hujan lebat, maka tidak akan begitu terasa dan jika hutan Bukit Duabelas terjaga, maka terjadi angin kencang, maka tidak akan begitu terasa, dan hutan Bukit Duabelas adalah juga sebagai tempat bermakam). ${ }^{17}$

Dalam memaknai hutan Bukit Duabelas sebagai pesako (ontologi substansi), masyarakat suku Orang Rimba memandang keberadaan hutan Bukit Duabelas tersebut adalah sebagai "keseimbangan kosmos dan keseimbangan sosial budaya", di mana gugusan Bukit Duabelas yang didiami masyarakat suku Orang Rimba telah menjadi ruang hidup suku Orang Rimba di mana dalam pemenuhan kebutuhan hidupnya sehari-hari dipenuhi melalui interaksi dengan alam hutan Bukit Duabelas dan dengan interaksi kebersamaan di antara mereka sendiri melalui berbagai kegiatan kearifan budaya hukum adatnya.

2. Hubungan antara persekutuan dan ruang hidupnya diartikan oleh Ter Haar Bzn, bahwa anggota-anggota persekutuan di dalam totalitasnya, menyelenggarakan hak ulayatnya dalam memanfaatkan dan memperoleh keuntungan dari ruang hidupnya tersebut termasuk binatang-binatang dan tetumbuhan yang hidup dengan liar di atasnya. ${ }^{18}$ Dalam hubungan antara hukum adat suku Orang Rimba dengan ruang hidupnya di Bukit Duabelas begitu mengikat tingkah laku Orang Rimba dan begitu ditaati, bagaimanapun kerasnya aturan hukum mereka, namun interaksi di antara mereka begitu lancar. Artinya, selain tradisional dan magis religius, sifat khas (aksidensi ontologi) dari hukum adat suku Orang Rimba yang bersifat komunal dan juga menaruh penghargaan yang mendalam kepada ikatanikatan hukum adatnya sehingga dapat menggugah sikap hormat dan melahirkan perilaku perlindungan dan perawatan terhadap ruang hidupnya. Berikut gambaran konstruksi ontologi hukum adat terhadap hak atas ruang hidup suku orang rimba di Taman Nasional Bukit Duabelas sebagaimana di dalam Gambar 1.

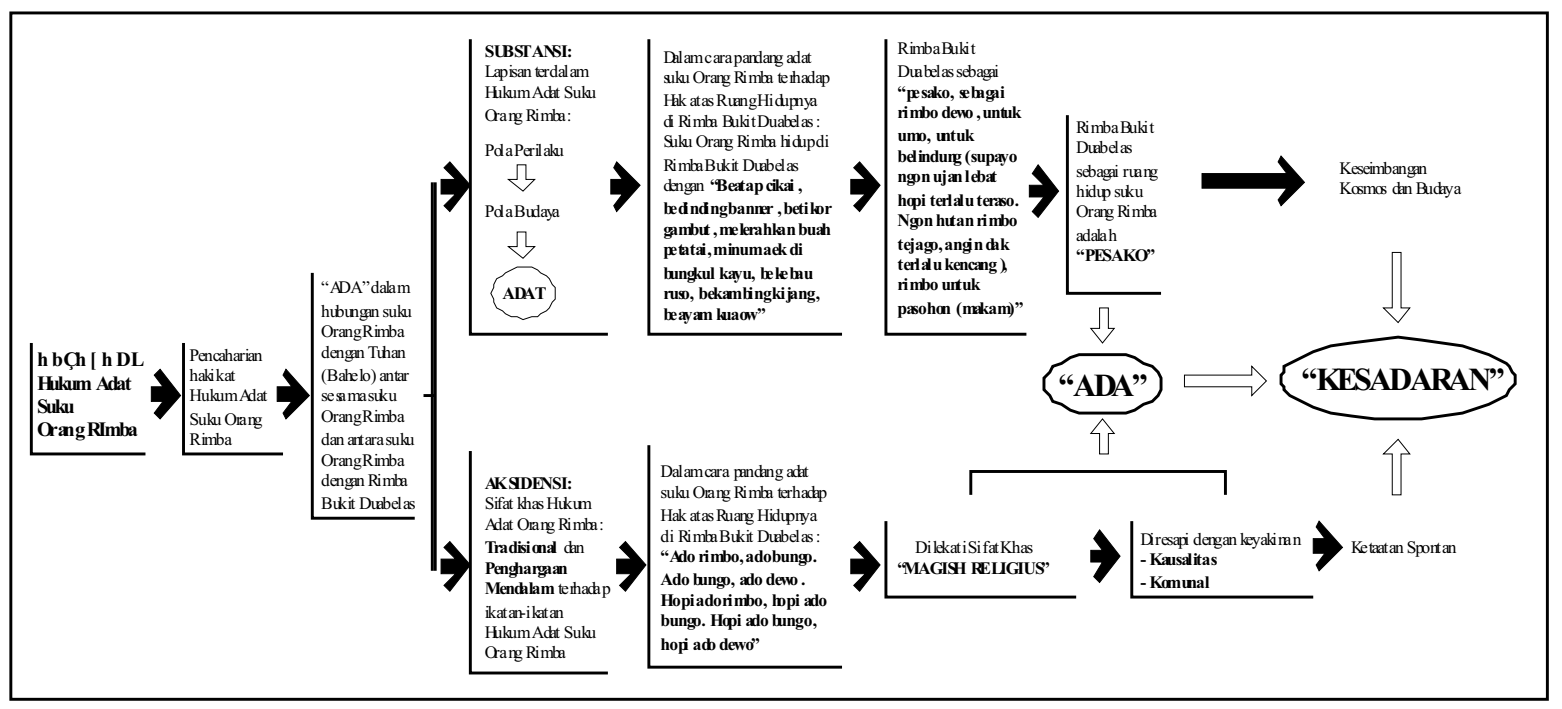

Gambar 1. Konstruksi Ontologi Hukum Adat terhadap Hak atas Ruang Hidup Suku orang rimba di Taman Nasional Bukit Duabelas

\footnotetext{
16. Hasil wawancara dengan Tarib, Tumenggung wilayah Kedundung Muda (Bukit Duabelas), Sabtu, 22 Agustus 2016.

17. Hasil wawancara dengan Besemen, Mangku adat wilayah Kedundung Muda (Bukit Duabelas), Senin, 25 Agustus

18. Ter Haar Bzn., 2011, Asas-asas dan Tatanan Hukum Adat, Bandung, CV Mandar Maju, hlm. 50.
} 


\section{Konstruksi Epistemologi Hukum Adat terhadap Hak atas Ruang Hidup Suku Orang Rimba di Taman Nasional Bukit Duabelas}

Terdapat dua pendekatan ketika memahami bagaimana sumber pengetahuan dari masyarakat suku Orang Rimba tersebut, yaitu: pertama, datang dari alam (natuur) yang diringi dengan sifat magis religius, atau yang disebut dengan fenomena yang ada, kedua, diproses dari hubungan di antara masyarakat suku Orang Rimba itu sendiri (kultur) yang dilekati dengan sifat tradisional.

Sumber pengetahuan hukum adat suku Orang Rimba terhadap hak atas ruang hidupnya di Bukit Duabelas adalah berangkat dari penghayatan terhadap alam nilai hidupnya bersama 'halom rimbo' (hutan Bukit Duabelas) yang menjadi ruang hidupnya secara tradisional. Artinya, pengetahuan Orang Rimba tentang ruang hidupnya di Bukit Duabelas itu merupakan proses yang melibatkan keyakinan yang berupa kesadaran, di mana terdapat hubungan antara subjek yang sadar (suku Orang Rimba) dengan objek yang dikenali (hutan Bukit Duabelas). Kesadaran tersebut terlihat dari berbagai upaya mengatasi krisis terhadap ruang hidupnya di Bukit Duabelas, yang mana dalam mereka menghambat laju pergerakan perladangan dan illegal logging lebih jauh ke dalam hutan, yakni dengan penanaman karet sebagai hompongon yaitu pagar di kawasan yang berbatasan langsung dengan desa.

Sementara dalam perihal pencaharian konstruksi berpikir epistemologi "kebenaran pengetahuan" hukum adat suku Orang Rimba terhadap hak atas ruang hidupnya di Bukit Duabelas, di mana "kebenaran" itu sendiri dipandang oleh Orang Rimba di Taman Nasional Bukit Duabelas adalah sebagai sesuatu yang dirindukan, karena menurut Orang Rimba: benor itu beik (benar itu adalah baik). ${ }^{19}$ Pengetahuan tersebut terjadi karena masyarakat suku Orang Rimba merasa sadar atas interaksinya dengan hutan Bukit
Duabelas sebagai ruang hidupnya. Artinya, pengetahuan atas kebenaran tersebut dibentuk oleh sikap dan lingkungan yang mempengaruhinya.

Apabila pengetahuan atas kebenaran tersebut dikaji melalui teori kebenaran korespondensi, dapat dibuktikan dari fakta bahwa pohon buah-buahan peninggalan leluhur mereka di hutan Bukit Duabelas yang sampai dengan saat ini keberadaannya begitu nyata dan dapat dinikmati oleh mereka. Kebenaran korespondensi merupakan kebenaran yang timbul apabila terdapat kesesuaian antara makna yang dimaksudkan oleh suatu pernyataan dengan apa yang sungguh-sungguh merupakan faktanya. ${ }^{20}$ Dari kebenaran sedemikian telah memperlihatkan bahwa epistemologi yang muncul dari pikiran suku Orang Rimba yang terbentuk dari tangkapan panca indera terhadap alam hutan Bukit Duabelas tersebut telah menimbulkan pola pikir hukum adat untuk membangun kehidupannya dengan melestarikan hutan Bukit Duabelas.

Sementara itu, kebenaran koherensi terjadi apabila suatu proposisi atau makna pernyataan dari suatu pengetahuan bernilai benar, jika proposisi itu mempunyai hubungan dengan ide-ide dari proposisi yang terdahulu adalah benar. ${ }^{21}$ Secara teori kebenaran koherensi, dapat diuji dari pemahaman suku Orang Rimba di Taman Nasional Bukit Duabelas yang memandang bahwa keberadaan magis religius Orang Rimba dalam hal ini dewa-dewa mereka ada di hutan Bukit Duabelas. Dari pemahaman tersebut, maka Orang Rimba memandang bahwa hutan Bukit Duabelas adalah sebagai ruang hidupnya.

Kebenaran pragmatis menunjukkan bahwa suatu pengertian itu hanya dapat menjadi benar kalau saja dapat dimanfaatkan secara praktis. ${ }^{22}$ Secara teori kebenaran pragmatis, dapat dibuktikan dari bahwa mereka selama ini telah mampu untuk mengurus hutan Bukit Duabelas secara benar dengan segala norma hukum adat dalam

19. Diolah dari hasil wawancara dengan Meratay, Depati wilayah Kedundung Muda (Bukit Duabelas), Kamis, 26 Mei 20. 2016 .

Abbas Hamami Mintaredja, Dasar-dasar Epistemologi, Makalah pada Internship Dosen-dosen Filsafat Ilmu Pengetahuan se-Indonesia tanggal 21 September s.d. 5 Oktober 1997 yang diselenggarakan oleh Fakultas Filsafat Universitas Gadjah Mada bekerja sama dengan Departemen Pendidikan dan Kebudayaan Republik Indonesia, hlm.

21. Ibid, hlm. 14

22.Ibid, hlm. 15. 
pengelolaannya secara arif dan dengan pantangan yang keras.

Dalam kebenaran semantik, proposisi itu mempunyai nilai kebenaran bila proposisi itu memiliki arti yang menunjuk kepada ciri yang khas dari sesuatu yang ada. ${ }^{23}$ Melalui teori kebenaran semantik, dapat dibuktikan dari kekhasan yang terkandung pada seloka adat suku Orang Rimba dengan cara hidup berikut ini:

Orang Rimba tinggal di rimba, "Beatap cikai, bedinding banner, betikar gambut, melerahkan buah petatal, minum aek di bungkul kayu, bekebau ruso, bekambing kijang, beayam kuaow". Sedangkan yang tinggal di dusun berpola hidup: "Bepadang pinang bepadang kelapo, besunat bebersihan, mengaji dan besekoloh, beternak kambing, beritik berangso, belamun bedusun, berumah betetanggo". ${ }^{4}$

Selain itu, yang juga menjadi ciri khas kebenaran semantik suku Orang Rimba terhadap hak atas ruang hidupnya di hutan Bukit Duabelas dapat dibuktikan dengan adanya kerifan budaya untuk melindungi hutan larangan yang dikenal dengan istilah hompongon, yakni dengan mengadakan jajaran kebun pembatas yang dibuat memanjang di bagian luar kawasan Taman Nasional Bukit Duabelas yang berfungsi untuk melindungi kawasan dalam TNBD dari perambahan liar.

Selanjutnya kebenaran pengetahuan epistemologi hukum adat suku Orang Rimba tersebut kemudian dihubungkan dengan prinsip-prinsip kebenaran epistemologi yang dalam hal ini terkandung pada empat prinsip dalam pengembangan kebenaran pengetahuan, yaitu: prinsip humanitas, prinsip holistik, prinsip tanggung jawab, dan prinsip kontekstualisasi. ${ }^{25}$

Prinsip humanis yang pada prinsipnya menekankan bahwa pengetahuan yang benar terhadap konteks hukum adat suku Orang Rimba dalam hubungannya dengan Bukit Duabelas sebagai ruang hidupnya dapat dibuktikan dari bagaimana kearifannya menempatkan lokasi-lokasi tertentu untuk keperluan yang sifatnya humanis seperti dalam pemanfaatan dan pengelolaan sumber daya di hutan Bukit Duabelas, Orang Rimba mengatur kedudukannya dalam bentuk wilayah yang terdiri atas rimbo, tempat beumo (beladang), kemudian yang menjadi sesap, lalu menjadi belukor, setelah itu menjadi benuaron. Selain itu, terdapat pula kawasan magis religius yang berupa tanoh peranokan dan tanoh pasaron.

Kedua, prinsip holistik terhadap konteks hukum adat suku Orang Rimba dalam hubungannya dengan Bukit Duabelas sebagai ruang hidupnya dapat dibuktikan dari bagaimana kearifannya pada sistem pembagian dari hasil berburu, di mana setiap kali mendapatkan hewan buruan yang besar, seperti babi atau rusa, bagian kepala diberikan kepada tumenggung (wujud pengakuan), sementara bagian dalam seperti jantung/hati diberikan kepada ayah mertua dari Orang Rimba yang berhasil mendapatkan hewan buruan tersebut (wujud penghormatan). Sebab kedua bagian itu hanya satu dan tidak dapat dibagi-bagi. Sisanya baru dibagibagikan rata kepada mereka yang ikut serta dalam berburu (wujud toleransi), dan kepada anggota kelompok mereka secara adil (wujud tolong menolong). ${ }^{26}$

Ketiga, prinsip tanggung jawab tercermin pada hukum adat suku Orang Rimba dalam hubungannya dengan kelestarian hutan Bukit Duabelas sebagai ruang hidup mereka. Keempat, prinsip kontekstualisasi, dalam hubungan antara hukum adat suku Orang Rimba dengan Bukit Duabelas sebagai ruang hidupnya dapat dibuktikan dari bagaimana kearifannya pada berbagai ritual kepercayaan Orang Rimba yang hanya dapat dilakukan di dalam hutan. Berikut gambaran konstruksi epistemologi hukum adat terhadap hak atas ruang hidup suku orang rimba di Taman Nasional Bukit Duabelas sebagaiamana di dalam Gambar 2.

23. Ibid, hlm. 16

24.Hasil wawancara dengan Besemen, Mangku adat wilayah Kedundung Muda (Bukit Duabelas), Minggu, 22 Mei 2016.

25.Aholiab Watloly, 2007, Tanggung Jawab Pengetahuan: Mempertimbangkan Epistemologi Secara Kultural, 26 Yogyakarta, Kanisius, hlm. 183-227.

.Hasil wawancara dengan Nggrip, Tumenggung wilayah Kedundung Muda (Bukit Duabelas), Selasa, 9 Februari 2016. 


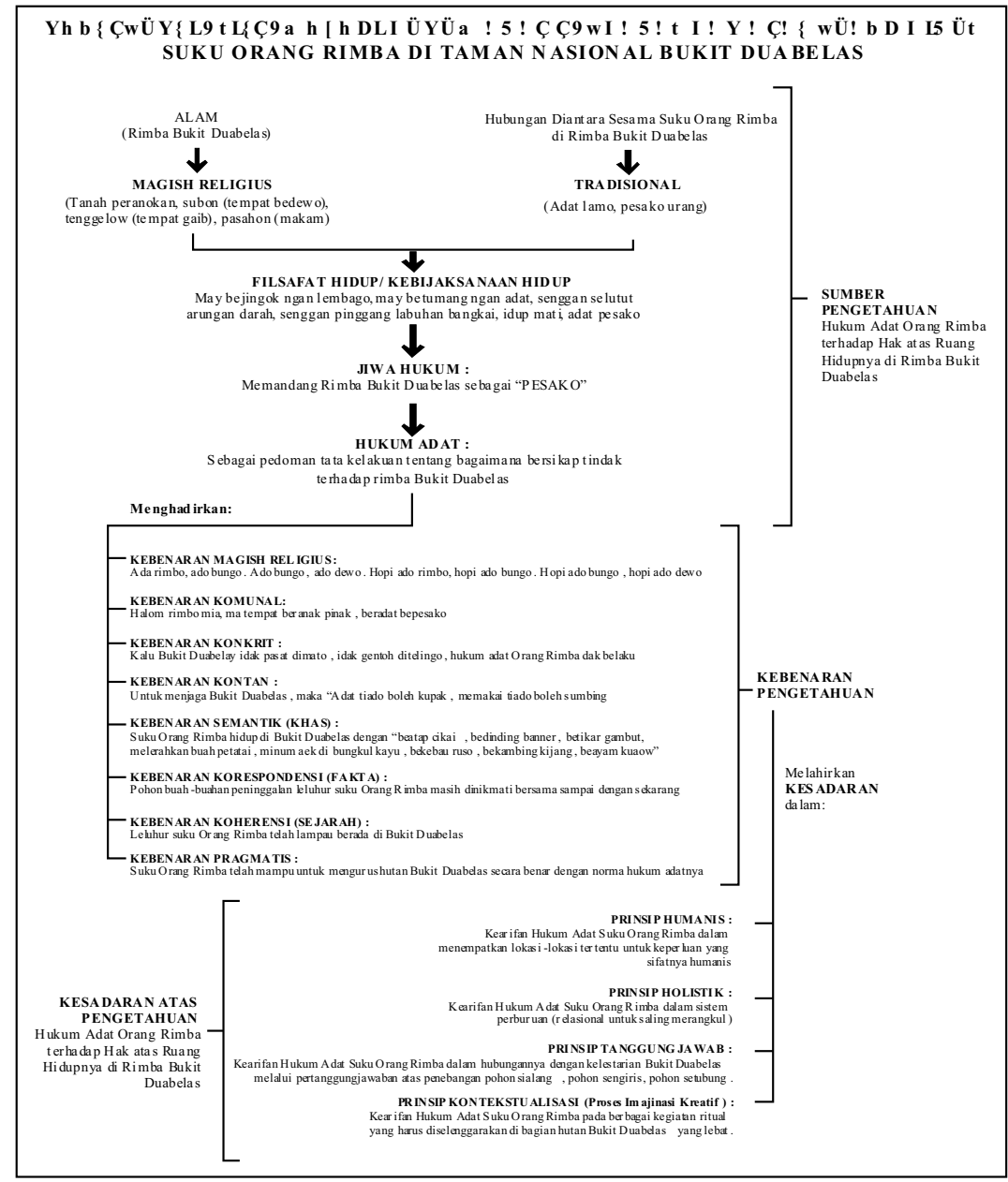

Gambar 2. Konstruksi Epistemologi Hukum Adat Terhadap Hak Atas Ruang Hidup Suku Orang Rimba di Taman Nasional Bukit Duabelas

\section{Konstruksi Aksiologi Hukum Adat terhadap Hak atas Ruang Hidup Suku Orang Rimba di Taman Nasional Bukit Duabelas}

Dalam konstruksi aksiologi hukum adat suku Orang Rimba dalam memandang ruang hidup hutan Bukit Duabelas terletak pada fungsi-fungsi tertentu (nilai kegunaan) untuk mencapai nilai sebagai tujuan. Pola pemanfaatan yang dimaksud pada ruang hidup suku Orang Rimba di hutan Bukit Duabelas tersebut, terdapat pada ruang hidup dalam fungsi sakral, fungsi sosial, dan fungsi pribadi. Keberhargaan alam hutan Bukit Duabelas sebagai ruang hidup suku Orang Rimba pada konstruksi berpikir nilai kegunaan aksiologi hukum adat suku Orang Rimba dalam fungsi sakral dikenal sebagai ruang untuk bedewo. Upacara bedewo pada dasarnya adalah memanggil dewa, ziarah memanjatkan doa, syukuran awal mulai berbungannya buah-buahan dan syukuran telah masaknya buah-buahan di hutan Bukit Duabelas.

Berangkat dari paradigma aksiologi hukum adat suku Orang Rimba dalam hubungannya dengan hak atas ruang hidupnya di hutan Bukit Duabelas pada nilai fungsi sakral yang sedemikian, kemudian telah menghadirkan nilai keberhargaan sebagai tujuan dalam wujud "nilai ketuhanan". Nilai ketuhanan dalam hukum adat suku Orang Rimba telah memberikan kesadaran dan sekaligus mendasari dan mewarnai hak atas ruang hidupnya dalam hubungan antara sesama mereka sendiri, Orang Rimba dengan Bukit Duabelas, dan Orang Rimba dengan Tuhan (Bahelo). Artinya, bagi masyarakat suku Orang Rimba hubungan-hubungan ini menjadi prioritas dalam seluruh sikap tindak hidupnya dan hak atas ruang hidupnya di hutan Bukit Duabelas. 
Dengan kelestarian Bukit Duabelas, berarti memelihara kerukunan hidup dengan sesama Orang Rimba, dan menjunjung tinggi Tuhan sebagai yang pencipta Orang Rimba dan Bukit Duabelas.

Cara pandang aksiologi hukum adat suku Orang Rimba terhadap alam (halom) hutan Bukit Duabelas yang berada pada fungsi sosial yaitu sebagai ruang hidup untuk keperluan bersama, terutama untuk upacaraupacara adat seperti perkawinan, pemberian nama untuk anak yang baru lahir, adanya anggota masyarakat suku Orang Rimba yang sakit parah, ataupun dalam upacara tolak balak. Selain itu, yang termasuk pula dalam keberadaan hutan Bukit Duabelas sebagai ruang hidup yang mengandung fungsi sosial bagi suku Orang Rimba juga terdapat pada peranannya sebagai ruang tempat bepekat berunding (bermusyawarah). Melalui cara pandang terhadap keberadaan hutan Bukit Duabelas sebagai ruang hidup suku Orang Rimba dalam konstruksi aksiologi hukum adatnya pada fungsi sosial telah menyadarkan bahwa nilai utama yang hendak dituju berada pada nilai kebersamaan, nilai kerukunan, dan nilai keadilan.

Secara umum, masyarakat suku Orang Rimba memahami nilai kerukunan sebagai suatu bentuk situasi yang dalam keadaan selaras, tenang, tentram, tanpa perselisihan dan pertentangan. Lebih sederhananya lagi, nilai kerukunan diterjemahkan oleh masyarakat suku Orang Rimba sebagai upaya pencegahan konflik diantara mereka. Artinya, rukun harus dipahami bukan sebagai sikap batin, melainkan merupakan penjagaan keselarasan dalam pergaulan di antara masyarakat suku Orang Rimba. Oleh karena itulah, perumusan norma hukum selokaseloka adat adat masyarakat suku Orang Rimba tersebut senatiasa dirumuskan dengan menggunakan bahasa yang halus agar supaya keselarasan hidup di antara sesama Orang Rimba dan di antara Orang Rimba dengan Bukit Duabelas dapat terjaga.

Cara pandang aksiologi hukum adat tersebut, pada dasarnya begitu mencerminkan adanya perumusan norma secara kausalitas relasi antara "Orang Rimba"-"Bukit
Duabelas", yang dengan sendirinya dapat memunculkan sikap menjaga keselarasan, keserasian, keharmonisan hubungan tersebut. Adapun konstruksi berpikir dari hukum adat suku Orang Rimba di Taman Nasional Bukit Duabelas terhadap nilai keadilan diterjemahkan dalam cara pandang sebagaimana seloka adat suku Orang Rimba berikut ini: ${ }^{27}$

Ular dipalu jangan mati;pemalu jangan patah;tanah dipalu jangan lemban;narik rambut dalam tepung; tepung jangan tebayak;rambut jangan putuy;dijual jangan jauh; dibunuhjangan mati.

Pelaksanaan hukum yang sedemikian, maka hukum akan menjadi paksaan sosial yang efektif dan dapat pula membantu untuk menjamin kekuatan ikatan hukum itu sendiri.

Keadilan di antara anggota masyarakat suku Orang Rimba merupakan obsesi dari seluruh masyarakat suku Orang Rimba. Cita keadilan senatiasa ditekankan untuk nilai kerukunan, sebab dengan begitu suasana kebersamaan, kehangatan dalam komunitas dapat dipertahankan, sehingga nilai rukun itu benar-benar dapat menyanggah keselarasan. Sementara, pada keberhargaan Bukit Duabelas sebagai ruang hidup suku Orang Rimba dalam fungsi pribadi pada konstruksi aksiologi hukum adat suku Orang Rimba dimaksudkan pada kegunaan hutan Bukit Duabelas sebagai tempat rumah (ghumah) dan ladang (umo) suku Orang Rimba.

Hubungan antara penghormatan terhadap ruang hidup pada ghumah ini dengan hukum adat suku orang Rimba di Bukit Duabelas berlaku seloka adat berikut: ${ }^{28}$

Ghumah kito bagi beradat; Tepian kito bagi bebaso.Terjemahannya: Berkunjung ke rumah Orang Rimba di Bukit Duabelas harus memiliki pengertian dengan aturan rumah/hutan Bukit Duabelas.

Apabila norma seloka adat tersebut dilanggar, maka akan berlaku denda sejumlah 60 lembar kain dan bahkan 120 lembar kain jika pelanggaran itu dilakukan di rumah tumenggung.

Fungsi ruang yang bersifat pribadi juga terdapat pada ladang (umo). Dalam hubungannya dengan ladang dalam fungsi

\footnotetext{
27. Hasil wawancara dengan Besemen, Mangku adat wilayah Kedundung Muda (Bukit Duabelas), Senin, 25 28 Februari 2016.

Hasil wawancara dengan Besemen, Mangku adat wilayah Kedundung Muda (Bukit Duabelas), 22 Mei 2016.
} 
ruang pribadi menurut keyakinan Orang Rimba pada dasarnya tidak dapat dilepaskan dengan keberadaan hutan Bukit Duabelas sebagai tanah adat (hak ulayat) atau milik bersama. Oleh karena itu, dalam pemahaman suku Orang Rimba di Bukit Duabelas, perladangan dalam fungsi pribadi yaitu dalam fungsi yang tersembunyi yang maknanya bukanlah atau tidak berperan sebagai pemilik lahan, akan tetapi hanya bertindak sebagai penggarap. Penggarapan lahan yang dimaksud mulai dari mencari lokasi, membuka lahan, mengerjakan lahan, menanam tanaman (umbi-umbian, jagung, karet, dan sebagainya), memelihara, sampai memungut hasilnya, sampai diwariskan. Sifat pemilikan dalam fungsi pribadi pada perladangan bukan pada lahannya, melainkan tanamannya (khususnya tanaman keras). Setiap anggota keluarga, laki-laki maupun perempuan, ikut berperan serta dalam mengelola ladangnya.

5. Dari gambaran tentang bagaimana hubungan antara suku Orang Rimba dengan hutan Bukit Duabelas sebagai ruang hidupnya dalam nilai sebagai fungsi pribadi tersebut, pada akhirnya kemudian menghadirkan nilai sebagai tujuan yang hendak dituju dalam bentuk nilai kemanusiaan. Nilai kemanusiaan pada konstruksi berpikir aksiologi hukum adat suku Orang Rimba dalam memandang hubungan antara keberadaan Orang Rimba dengan Bukit Duabelas sebagai ruang hidupnya pada dasarnya begitu dihubungkan dengan etika dan moral. Berikut gambaran konstruksi aksiologi hukum adat terhadap hak atas ruang hidup suku orang rimba di taman nasional bukit duabelas sebagaimana di dalam Gambar 3.

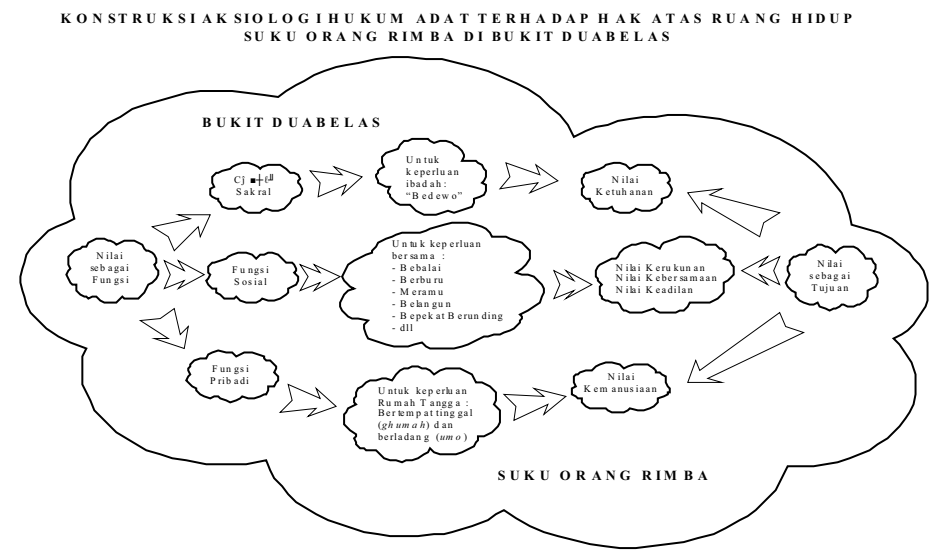

Gambar 3. Konstruksi Aksiologi Hukum Adat terhadap Hak atas Ruang HidupSuku Orang Rimba di Taman Nasional Bukit Duabelas

\section{Simpulan}

Hakikat hak atas ruang hidup suku Orang Rimba di hutan Bukit Duabelas pada dasarnya terletak di antara (sintesis) pemahaman terhadap substansi di satu pihak dengan pemahaman terhadap sifat khas (aksidensi) pola hubungan di pihak lain. Pemahaman tersebut didukung dengan cara pandang suku Orang Rimba terhadap hutan Bukit Duabelas yang tidak hanya dipandang sebagai materi yang menjadi bahan dasar terbentuknya kosmos, namun juga dipandang 'ada' yang memungkinkannya menjadi sebagaimana adanya.

Sumber pengetahuan hukum adat suku Orang Rimba terhadap hak atas ruang hidupnya di Bukit Duabelas adalah berangkat dari penghayatan terhadap alam nilai hidupnya bersama 'halom rimbo' (hutan Bukit Duabelas) yang menjadi ruang hidupnya secara tradisional. Sementara dalam konstruksi berpikir epistemologi "kebenaran pengetahuan" hukum adat suku Orang Rimba terhadap hak atas ruang hidupnya di Bukit Duabelas, di mana menurut Orang Rimba: benor itu beik (benar itu adalah baik). Pengetahuan tersebut terjadi karena masyarakat suku Orang Rimba merasa sadar atas interaksinya dengan hutan Bukit Duabelas sebagai ruang hidupnya melalui prinsip humanis, holistik, tanggung jawab dan kontekstualisasi.

Dari segenap gambaran konstruksi aksiologi hukum adat suku Orang Rimba, baik dalam konteks nilai sebagai fungsi maupun nilai sebagai tujuan dalam memandang bagaimana hubungan antara suku Orang Rimba dengan hak atas ruang hidupnya di hutan Bukit Duabelas tersebut, maka dapat disimpulkan bahwa pada dasarnya di antara kedudukan nilai sebagai kegunaan dan nilai sebagai tujuan dari kearifan hukum adat suku Orang Rimba di Taman Nasional Bukit Duabelas tersebut pada dasarnya memiliki keterkaitan antara satu nilai dengan nilai lainnya.

\section{Daftar Pustaka}

Bzn Ter Haar, 2011, Asas-asas dan Tatanan Hukum Adat, Bandung, CV Mandar Maju.

Erwin Muhamad, 2016, Filsafat Hukum: 
Refleksi Kritis Terhadap Hukum dan Hukum Indonesia (Dalam Dimensi Ide dan Aplikasi), Jakarta, PT RajaGrafindo Persada.

Hamami Mintaredja Abbas, Dasar-dasar Epistemologi, Makalah pada Internship Dosen-dosen Filsafat Ilmu Pengetahuan se-Indonesia tanggal 21 September s.d. 5 Oktober 1997 yang diselenggarakan oleh Fakultas Filsafat Universitas Gadjah Mada bekerja sama dengan Departemen Pendidikan dan Kebudayaan Republik Indonesia.

Rahardjo Satjipto, 2009, Hukum Progresif: Sebuah Sintesa Hukum Indonesia, Yogyakarta, Genta Publishing.

Rato Dominikus, 2015, Hukum Adat Kontemporer, Surabaya, LaksBang Justitia.

Santoso M. Agus, 2012, Hukum, Moral, \& Keadilan: Sebuah Kajian Filsafat, Jakarta, Kencana Prenada Media Group.

Salman Soemadiningrat Otje, 2011, Rekonseptualisasi Hukum Adat Kontemporer, Bandung, PTAlumni.

Sudaryatmi Sri, "Peranan Hukum Adat dalam Pembangunan Hukum Nasional di Era Globalisasi", Jurnal Masalah-Masalah Hukum, Vol. 41, No. 4, Oktober 2012.

Udayati Agni, dkk., 2013, Mohammad Koesnoe Dalam Pengembaraan Gagasan Hukum Indonesia, Jakarta, Epistema Institute dan HUMA.

Watloly Aholiab, 2007, Tanggung Jawab Pengetahuan: Mempertimbangkan Epistemologi Secara Kultural, Yogyakarta, Kanisius.

Wignjosoebroto Soetandyo, 2007, Hukum Dalam Masyarakat (Perkembangan dan Masalah), Sebuah Pengantar Ke Arah Kajian Sosiologi Hukum, Malang, Bayu Media.

Yuli Sulistyawan Aditya, "Mempersoalkan Objektivitas Hukum: Suatu Perbincangan Filsafat Hukum", Jurnal Masalah-Masalah Hukum, Vol. 41, No. 4, Oktober 2012.

International Covenant on Economic, Social and Cultural Rights 